\title{
MODEL OF PROGRESSIVE FAILURE FOR COMPOSITE MATERIALS USING THE 3D PUCK FAILURE CRITERION
}

\author{
MODEL POSTOPNEGA POPUŠČANJA KOMPOZITNEGA \\ MATERIALA Z UPORABO PUCKOVEGA TRIDIMENZIONALNEGA \\ KRITERIJA PORUŠITVE
}

\author{
Lukáš Bek, Robert Zemčík \\ University of West Bohemia, European Centre of Excellence, Faculty of Applied Sciences, NTIS - New Technologies for the Information \\ Society, Univerzitní 22, 30614 Pilsen, Czech Republic \\ lukasbek@kme.zcu.cz \\ Prejem rokopisa - received: 2014-09-16; sprejem za objavo - accepted for publication: 2015-05-07
}

doi: $10.17222 /$ mit. 2014.233

\begin{abstract}
A model for the progressive failure of composite materials that considers the materials' non-linearity was developed and implemented with the Abaqus FE software. An extended Puck failure criterion for the 3D stress state was used for the failure prediction. Furthermore, a simplified approach for the simulation of the delamination was considered. For the progressive failure simulation, the stiffness matrix degradation was used and the degradation parameters were a function of the fracture angle. The model was tested on problems of a pin-loaded composite plate and of a composite tube subjected to compressive loading perpendicular to the tube axis.

Keywords: progressive failure, composite, Puck criterion, finite-element analysis
\end{abstract}

Razvit je bil model postopnega popuščanja kompozitnega materiala z upoštevanjem nelinearnosti materiala, ki je bil uporabljen v Abaqus FE programski opremi. Razširjeni Puckov kriterij porušitve za tridimenzionalno napetostno stanje je bil uporabljen za napoved porušitve. Poleg tega je bil uporabljen tudi poenostavljen približek za simulacijo delaminacije. Za simulacijo napredovanja popuščanja je bila uporabljena degradacija togosti matrice. Degradacijski parametri pa so bili funkcija kota porušitve. Model je bil preizkušen na problemu obremenjevanja kompozitne plošče s konico in kompozitne cevi, izpostavljene tlačni obremenitvi pravokotno na os cevi.

Ključne besede: postopno popuščanje, kompozit, Puckov kriterij, analiza končnih elementov

\section{INTRODUCTION}

Composite materials are frequently used in the aerospace, automotive and marine industries, where extremely strong components and structures are necessary. Due to the complex loading, finite-element (FE) analyses are frequently used for the investigation of the stress state and the failure of structures. ${ }^{1}$ Commercial FE software systems are usually able to predict only the first failure, which can occur at $20 \%$ of the total strength of composite structures. Some new releases of FE systems are able to perform progressive failure analyses. However, the analyses are often not sufficiently precise or have problems with numerical stability. Therefore, new models of progressive failure are developed and implemented into the FE systems using a user-defined material subroutine. ${ }^{2}$

The development, implementation and testing of the progressive failure model for the 3D stress state based on the Puck failure criterion and considering the material's non-linearity in the Abaqus FE software using the UMAT material subroutine was the aim of this investigation.

\section{NON-LINEAR MATERIAL BEHAVIOUR}

For the simulation of the non-linear material behaviour of composite materials, a non-linear function with a constant asymptote was used for the calculation of the shear modulus $G_{12}$ and $G_{13}:^{3}$

$$
\begin{aligned}
& G_{12}\left(\gamma_{12}\right)=\frac{G_{12}^{0}}{\left[1+\left(\frac{G_{12}^{0} \cdot \gamma_{12}}{\tau_{12}^{0}}\right)^{n_{12}}\right]^{1+\frac{1}{n_{12}}}} \\
& G_{13}\left(\gamma_{13}\right)=\frac{G_{12}^{0}}{\left[1+\left(\frac{G_{12}^{0} \cdot \gamma_{13}}{\tau_{12}^{0}}\right)^{n_{12}}\right]^{1+\frac{1}{n_{12}}}}
\end{aligned}
$$

where $G_{12}{ }^{0}$ is the initial shear modulus, $\gamma_{12}$ and $\gamma_{13}$ are the shear strains, $\tau_{12}{ }^{0}$ is the asymptote value of the shear stress and $n_{12}$ is the shape parameter.

\section{FAILURE CRITERION}

The failure criterion determines the occurrence of failure and indicates the failure's propagation. The Puck 
criterion for the $3 \mathrm{D}$ stress state, described in ${ }^{2,4}$, was selected for this model because it provides the fracture angle $\theta_{f r}$, later used for the stiffness degradation. Furthermore, the influence of the fibre parallel-stress extension and the influence of the non-fracture plane extension were used with this criterion. ${ }^{4}$

\section{PROGRESSIVE FAILURE IN THE CASE OF INTER-FIBRE FAILURE}

The stiffness-matrix degradation method was used to simulate the progressive failure. In order to simplify the determination of the degradation parameters, the stiffness matrix $C$, in UMAT, called DDSDDE, was transformed from the material coordinate system $(1,2,3)$ to the crack coordinate system $(x, y, z)$ described in Figure 1.

The transformation of the $C$ matrix in the $(1,2,3)$ system to the $C^{\prime}$ in the $(x, y, z)$ system was carried out using the Equation (3):

$$
C^{\prime}\left(\theta_{\mathrm{fr}}\right)=T_{\sigma} \cdot C \cdot T_{\varepsilon}^{-1}
$$

where

$$
T_{\sigma}=\left[\begin{array}{cccccc}
1 & 0 & 0 & 0 & 0 & 0 \\
0 & c^{2} & s^{2} & 0 & 0 & 2 s c \\
0 & s^{2} & c^{2} & 0 & 0 & -2 s c \\
0 & 0 & 0 & c & s & 0 \\
0 & 0 & 0 & -s & c & 0 \\
0 & -s c & s c & 0 & 0 & c^{2}-s^{2}
\end{array}\right]
$$

is the transformation matrix for the stress vector and $T_{\varepsilon}^{-1}$ is the inverted transformation matrix

$$
T_{\varepsilon}=\left[\begin{array}{cccccc}
1 & 0 & 0 & 0 & 0 & 0 \\
0 & c^{2} & s^{2} & 0 & 0 & s c \\
0 & s^{2} & c^{2} & 0 & 0 & -s c \\
0 & 0 & 0 & c & s & 0 \\
0 & 0 & 0 & -s & c & 0 \\
0 & -2 s c & 2 s c & 0 & 0 & c^{2}-s^{2}
\end{array}\right]
$$
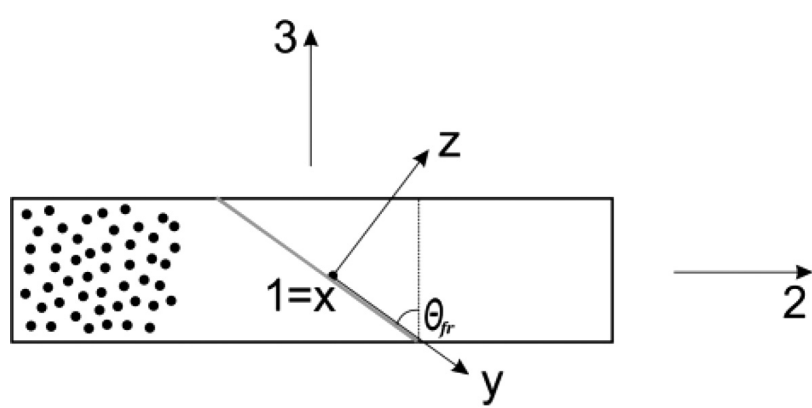

Figure 1: Description of the material coordinate system $(1,2,3)$ and the crack coordinate system $(x, y, z)$

Slika 1: Opis koordinatnega sistema materiala $(1,2,3)$ in koordinatnega sistema razpoke $(x, y, z)$ for the strain vector. In Equations (4) and (5), $c$ represents $\cos \theta_{f r}$ and $s$ represents $\sin \theta_{f r}$.

The non-zero components of the $C^{\prime}$ matrix $C_{\mathrm{ij}}$ ' are multiplied by $\left(1-d_{\mathrm{ij}}\right)$ terms. The degradation parameters $d_{\mathrm{ij}} \in\langle 0,1\rangle$ are constant values and differ for tensile and compressive failure.

Afterwards, the $C$ ' matrix is transformed back from the $(x, y, z)$ system to the $(1,2,3)$ system using the transformation matrices:

$$
C^{\prime \prime}\left(d_{\mathrm{ij}}\right)=T_{\sigma}^{-1} \cdot C^{\prime}\left(\theta_{\mathrm{fr}}, d_{\mathrm{ij}}\right) \cdot T_{\varepsilon}
$$

\section{PROGRESSIVE FAILURE IN THE CASE OF FIBRE FAILURE}

The transformation of the $C$ matrix is not necessary. Therefore, the non-zero components of the $C$ matrix $C_{\mathrm{ij}}$ are only multiplied by $\left(1-d_{\mathrm{ij}}\right)$ terms, as in the case of inter-fibre failure.

\section{DELAMINATION}

During the testing it was observed that delamination must be considered because after the initial fibre or inter-fibre failure, the crack often propagates in the form of a delamination. Therefore, an approach for the simulation of the delamination was also implemented.

A thin isotropic layer of brittle matrix was inserted between each of the orthotropic layers in the FE model. For the prediction of the matrix failure, the maximum stress criterion, originally used for orthotropic materials, was considered because it provides information about which stress component suffered failure. The normal stress components were compared to the compressive and tensile strengths of the matrix, while the shear components were compared to the shear strength of the matrix.

In the case of the failure, the non-zero components of the $C$ matrix $C_{\mathrm{ij}}$ are again multiplied by $\left(1-d_{\mathrm{ij}}\right)$ terms as in the case of inter-fibre failure.

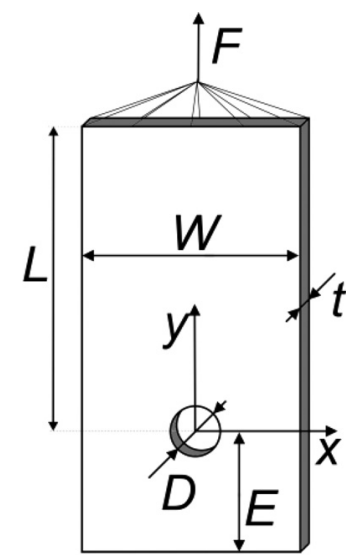

Figure 2: Geometric properties of the pin-loaded plate Slika 2: Geometrijske lastnosti s konico obremenjene plošče 


\section{CASE STUDY 1 - PIN JOINT}

First, in order to test the model, the failure simulations of pin-loaded carbon composite plates were compared with the experiments. Two types of specimens with different failure modes (shear-out and net-tension ${ }^{5}$ ) were selected for the failure simulation. The geometric properties of the specimens are described in Figure 2, where the $0^{\circ}$ layup orientation is parallel to the $y$ axis and the pin diameter $D=8 \mathrm{~mm}$.

The failure simulation for the first type of specimens with the shear-out failure mode, a composite layup $\left[0^{\circ}\left|45^{\circ}\right|-45^{\circ} \mid 90^{\circ}\right] \mathrm{s}$, ratios $E / D=1$ and $W / D=3$, and a thickness $t=2.32 \mathrm{~mm}$, is illustrated in Figure 3. The black colour indicates the elements with a degraded

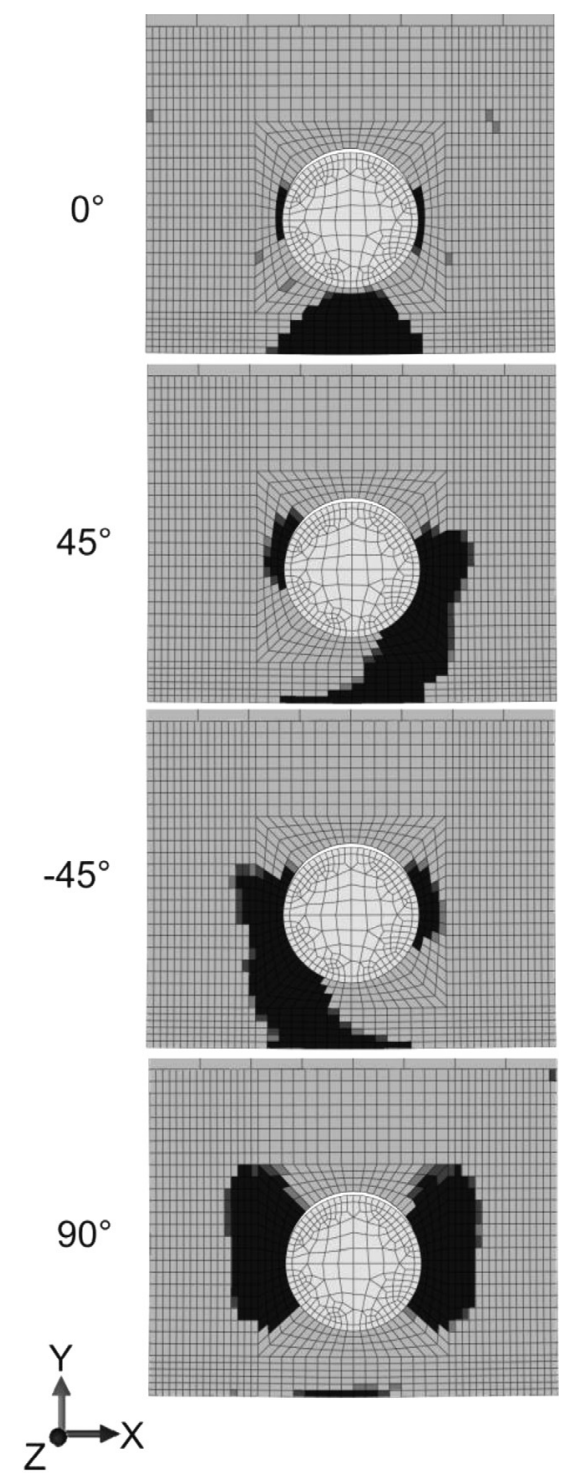

Figure 3: Numerical simulation of the final shape of failure in the case of specimens with a shear-out failure mode; different layers displayed

Slika 3: Numerična simulacija končne oblike porušitve v primeru vzorca s porušitvijo z izstriženjem; prikazane so različne plasti

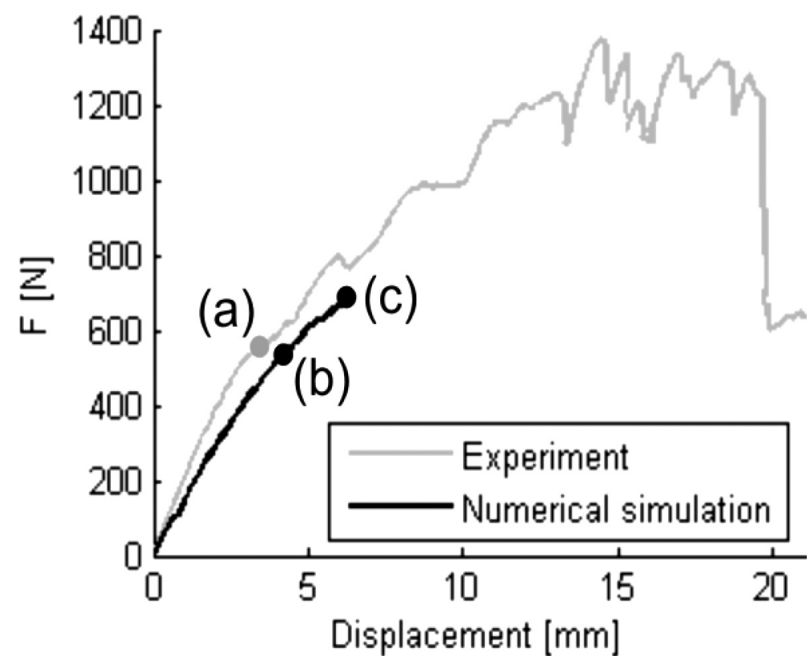

Figure 4: Load-displacement diagrams of the experiment and the numerical simulation: a) first failure investigated using experiment, b) first failure investigated using numerical simulation and c) loss of numerical stability

Slika 4: Diagram obremenitev-raztezek eksperimenta in numerične simulacije: a) prva preiskovana porušitev pri eksperimentu, b) prva preiskovana porušitev pri numerični simulaciji in c) izguba numerične stabilnosti

stiffness matrix and represents the failure of the material. All the layers representing the isotropic matrix were also degraded. The error for the ultimate load $F$ was $6.8 \%$ (compared to the average value from the experiments).

The error for the ultimate load $F$ investigated using the failure simulation of the second type of specimens with a net-tension failure mode, a composite layup $\left[90^{\circ}\left|45^{\circ}\right|-45^{\circ} \mid 0^{\circ}\right] \mathrm{s}$, ratios $E / D=4$ and $W / D=2$, and a thickness $t=2.32 \mathrm{~mm}$ was $10.9 \%$ (compared to the average value from the experiments as well).

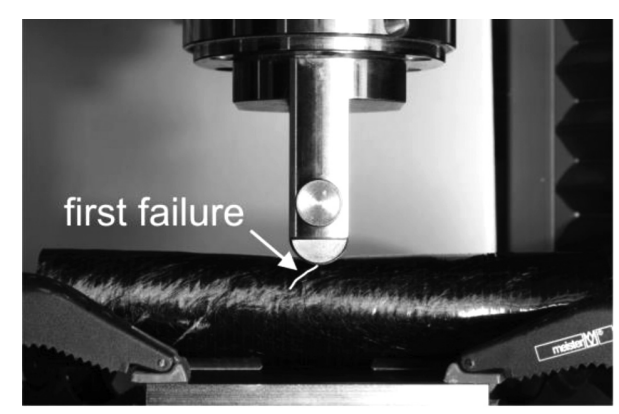

(a)

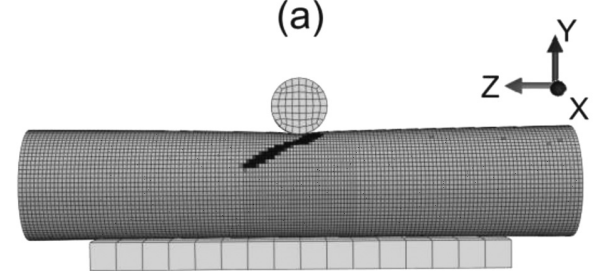

(b)

Figure 5: Comparison of the position and shape of the first failure investigated using the experiment and the numerical simulation

Slika 5: Primerjava položaja in oblike prve porušitve pri preizkusu in pri numerični simulaciji 


\section{Outer layer $45^{\circ}$}

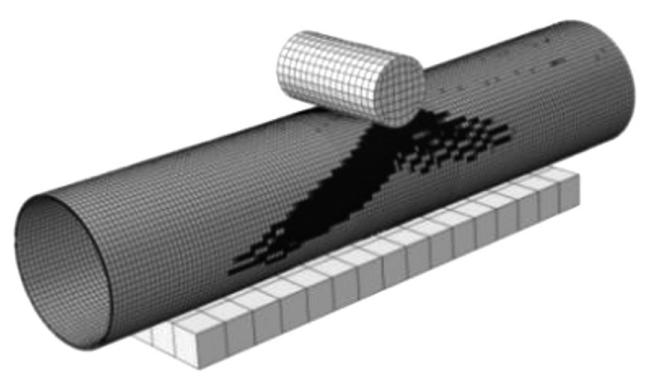

Inner layer $-45^{\circ}$

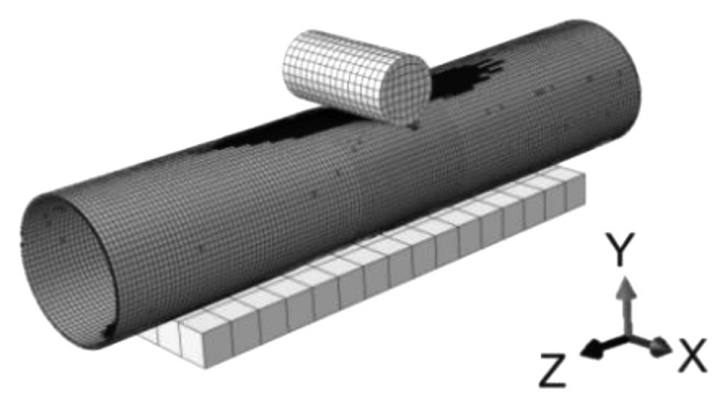

Figure 6: Numerical simulation of the shape and the position of failure just before the loss of numerical stability

Slika 6: Numerična simulacija oblike in položaja poškodbe tik pred izgubo numerične stabilnosti

\section{CASE STUDY 2 - COMPOSITE TUBE}

In addition, the testing was carried out on a thinwalled composite tube subjected to compressive loading perpendicular to the tube's axis. The tube consisted of carbon fibres with a composite layup $\left[45^{\circ} \mid-45^{\circ}\right]$, a wall-thickness of $1 \mathrm{~mm}$ and an outer diameter of $42 \mathrm{~mm}$. The length of the tested tube was $200 \mathrm{~mm}$.

A stiffness comparison of the experiment and the numerical simulation is illustrated in Figure 4. A comparison of the position and the shape of the first failure investigated using the experiment (Figure 4a) and the numerical simulation (Figure 4b) is illustrated in Figure 5. Unfortunately, the numerical model was not able to simulate the whole specimen failure due to a loss of numerical stability. In Figure 6, the failure just before the loss of numerical stability in both layers is illustrated. The error of the simulation at this point (Figure 4c) is $13.8 \%$.

\section{CONCLUSION}

Our model of progressive failure using the extended Puck failure criterion for the 3D stress state and considering the simplified approach for the simulation of delamination and the material's non-linearity showed very good agreement between the numerical simulation and the experiments. The error for all the simulations was below $14 \%$. In future work, the problem of numerical stability will be further investigated.

\section{Acknowledgements}

This work was supported by the European Regional Development Fund (ERDF), project "NTIS - New Technologies for Information Society", European Centre of Excellence, CZ.1.05/1.1.00/02.0090, by the research project GACR_P101/11/0288 and by the grant project SGS-2013-036.

\section{REFERENCES}

${ }^{1}$ V. Lašová, P. Bernardin, Numerical modelling of glued joints between metal and fibre composites using cohesive elements, Applied Mechanics and Materials, 611 (2014), 156-161, doi:10.4028/ www.scientific.net/AMM.611.156

${ }^{2}$ H. M. Deuschle, 3D Failure Analysis of UD Fibre Reinforced Composites: Puck's Theory within FEA, Institut für Statik und Dynamik der Luft- und Raumfahrtkonstruktionen, Universität Stuttgart, Stuttgart 2010

${ }^{3}$ J. Krystek, T. Kroupa, R. Kottner, Identification of mechanical properties from tensile and compression tests of unidirectional carbon composite, $48^{\text {th }}$ International Scientific Conference proceedings: Experimental Stress Analysis 2010, Palacky University, 2010, 193-200

${ }^{4}$ A. Puck, Festigkeitsanalyse von Faser-Matrix-Laminaten: Modele für die Praxis, Carl Hanser Verlag, München, Wien 1996

${ }^{5}$ H. Schürmann, Konstruieren mit Faser-Kunststoff Verbunden, Springer Verlag, Berlin, Heidelberg 2007, doi:10.1007/978-3-540-72190-1 